\title{
COVID-19, Aged Care, Cancer, Medical Research and Mental Health
}

\author{
Lindsay B. Carey ${ }^{1}$
}

Accepted: 29 October 2020 / Published online: 10 November 2020

(c) Springer Science+Business Media, LLC, part of Springer Nature 2020

\section{Introduction and Milestones}

This last issue for 2020 of the Journal of Religion and Health (JORH 2020a) recognizes a number of milestones relating to: COVID-19, aged care, cancer, various medical research, mental health, and the JORH Editorial. The first milestone I wish to mention is with regard to Reverend Curtis Hart retiring as JORH Editor-in-Chief. The last 10 years of JORH under Curt's editorship have been extraordinary. For those of us who are loyal JORH readers and, even more so, for those of us who are producers of research and script, Curt became (perhaps unwittingly) an invaluable mentor for many around the world (including myself) by encouraging research and discussion concerning the correlation between religion and health. Subsequently, this assisted the growth of these two interdisciplinary areas and the rise of JORH as a valuable and resourceful medium for academics and clinicians. We warmly and wholeheartedly thank Curtis Hart for his dedication and distinguished service to $J O R H$ and the international community.

\section{COVID-19}

Another milestone noted with this JORH issue is the ongoing COVID-19 pandemic and the pastoral responses to its deathly results around the globe. JORH led the way with a special section on COVID-19 (JORH 2020b), providing resources to inform, educate, and support international communities (Hart and Koenig 2020). Similar journals also followed suit with a special issue in response to the pandemic (e.g., Carey et al 2020), whereas other journals to date have only provided editorial commentary (e.g., Bard 2020). Some journals have not even addressed the issue-perhaps believing COVID-19 would be of little significance! In this issue, JORH proves its flexibility and currency by including additional articles addressing COVID-19

Lindsay B. Carey

Lindsay.Carey@latrobe.edu.au

1 Palliative Care Unit, Department of Public Health, La Trobe University, Melbourne, Australia 
as a follow-on to the previously published special edition on COVID-19 (JORH 2020b). The first of these articles considers religion and faith perceptions during the COVID-19 pandemic, then subsequently religious clichés and stigma as a result of COVID-19, Jewish ethical justifications for medical quarantine, as well as a personal reflection offering hope during COVID-19. Future, JORH issues will contain other articles concerning COVID-19.

\section{Aged Care}

An additional milestone, noted by Goldin and Muggah (2020) within their global epidemiological text "Terra Incognita," is that, for the first time in history, this decade marks the turning point when "the over-sixty set are among the fastest-growing age group in the world" (p. 372). Further to this, they provide evidence indicating that "the number of people aged sixty and over will more than double in the next three decades from roughly 926 million to 2.1 billion by 2050" (p. 372). There should be little surprise that aged care is, and will become, increasingly important.

This issue includes research relating to elderly care by nursing students from Saudi Arabia, paternal age and religious behavior among pre- and post-60's US birth cohorts, religious/spiritual practices among elderly Indian rural woman, religious/ spiritual practices among Mexican older adults with geriatric syndromes, religious struggle and life satisfaction among Polish adult Christians (18-79 years), assessment of mental health among elderly Iranians with chronic pain, the role of private religious practices and spiritual mindfulness among US widowed adults, the impact of perceived social support among elderly in Pakistan, and lastly a reflective discussion about spirituality and caring for the older person.

\section{Cancer}

While COVID-19 continues to dominate headlines, people with cancer are still battling this far more prevalent disease; mostly lung and colon cancer, but particularly for women, breast cancer, and for men, prostate cancer-all of which can have a religious/spiritual impact (Koenig et al. 2012, pp. 439-467). Most cancers, but not all, are deemed "non-communicable" because these are non-transmissible directly from one person to another. In the future, however, this perspective may well change as society increasingly recognizes that we do in fact directly pass on, from one to another, community to community, generation to generation, culture to culture, numerous individual and social determinants which can solicit the development of cancer (e.g., poor diets and/or unhealthy lifestyles). It can be argued that the two main inhibitors regarding the prevention and treatment of cancer are lack of government commitment and inadequate research funding. If only nations would enthusiastically seek a solution for cancer as earnestly as a vaccine for COVID-19.

With regard to cancer, this issue considers the effect of spiritual care on anxiety among Iranian adolescents with cancer, religious coping and the levels of hope among cancer patients receiving chemotherapy, an evaluation of religious coping 
in Tunisian Muslim women with newly diagnosed breast cancer, health-related factors with regard to the spiritual well-being of cancer patients, the power of religious beliefs and coping with cancer from an Iranian parental perspective, the spiritual beliefs of Jordanian adult patients receiving palliative care and, finally, family attitudes toward physician-led spiritual care in pediatric palliative medicine.

\section{Medical Research}

Similar to previous JORH issues, medical conditions and associated research that consider religious and spiritual factors dominate the current issue. The articles included in this issue pertain to blood management education, sickle cell disease, Beta thalessmia major, blood donation, bone grafting, pregnant brain-death patients and malformed fetuses, Cardiovascular related concerns are also considered such as cardiovascular stress, cardiovascular disease, cardiovascular functioning, hypertension, stroke, and post-traumatic CPR stress. Obesity and diabetes are also considered, as well as kidney disease and hemodialysis, hepatitis, and, lastly, insomnia. The next issue will also contain further articles considering medical conditions and any religious/spiritual affiliations.

\section{Mental Health}

Another contemporary and increasingly prevalent topic is with respect to mental health and religion/spirituality which can involve either health-promoting or deleterious effects (Griffith 2012). This issue covers the impact of fasting upon psychological well-being, women in substance abuse treatment, orthopsychiatry and cultural diversity, the effect of religious and Islamic teachings on the calmness and mental health in educational spaces, a study of mental health and religiosity among Muslim students, prevalence of "social media disorder" among Muslim university students in Pakistan, spiritual and somatoform dissociation among Chinese Buddhists, religiosity and depressive symptoms in young adults, determinants of congregational attendees' psychological outcomes, and finally clergy attitudes concerning ways to support the mental health of sexual and gender minorities.

\section{Looking Forward: 2021}

Unless a vaccine becomes readily available, COVID-19 will undoubtedly, similar to previous pandemics, dominate both health, economic, and geopolitical multipolar issues for many months, and recovery will require years. Consideration, however, should also be given to other issues. Two that seem obvious are the topic of moral injury (both military and civilian), which is slowly gaining increasing recognition with regard to religious/spiritual factors (Hodgson and Carey 2017), and 
"Remembering September 11," as next year will mark two decades since that devastating event. Authors are encouraged to consider these topics for submissions to JORH.

\section{B. Carey \\ JORH Associate Editor}

\section{References}

Bard, T. R. (2020). A COVID-19 educational sidebar: Humble curiosity. Journal of Pastoral Care and Counselling, 74(3), 157-158. https://doi.org/10.1177/1542305020952532

Carey, L. B., Swift, C., \& Burton, M. (2020). COVID-19: multinational perspectives of providing chaplaincy, pastoral, and spiritual care. Health and Social Care Chaplaincy, 8(2), 133-142. https://doi. org/10.1558/hscc. 41973

Goldin, I., \& Muggah, R. (2020). Terra incognita: 100 maps to survive the next 100 years. London: Penguin. https://www.penguin.com.au/books/terra-incognita-9781529124194

Griffith, J. L. (2012). Psychiatry and mental health treatment. In M. Cobb, C. Puchalski, \& B. Rumbold (Eds.), Oxford Textbook of Spirituality in Healthcare (pp. 227-234). Oxford: Oxford University Press. ISBN: 978-0-19-957139-0.

Hart, C. W., \& Koenig, H. G. (2020). Special section: Religion and health response to the COVID-19 pandemic. Journal of Religion and Health, 59(5), 2191-2192. https://doi.org/10.1007/s10943-02001085-6

Hodgson, T. J., \& Carey, L. B. (2017). Moral injury and definitional clarity: Betrayal, spirituality and the role of chaplains. Journal of Religion Health, 56, 1212-1228. https://doi.org/10.1007/s1094 3-017-0407-z

JORH. (2020a). Journal of Religion and Health, 59(6). (Access: https://link.springer.com/journal/10943/ volumes-and-issues/59-6)

JORH. (2020b). Journal of Religion and Health, 59(5). (Access: https://link.springer.com/journal/10943/ volumes-and-issues/59-6)

Koenig, H., King, D. E., \& Carson, V. B. (2012). Handbook of religion and health. New York: Oxford University Press. ISBN: 978-0-19-533595-8.

Publisher's Note Springer Nature remains neutral with regard to jurisdictional claims in published maps and institutional affiliations. 